\title{
BIO-BANDING from concept to practice in sports
}

'Bio-banding will create better leaders and people' by Pete Lansley

\section{Alexandra Mihaela STĂNILĂ¹, Marius MATICHESCU LUPȘA², Cătălin STĂNILĂ}

\begin{abstract}
Introduction: The bio-banding (BB) concept refers to the practice of grouping athletes based on attributes associated with growth and maturation instead of chronological age. Lately, the advantages and disadvantages of bio-banding are widely debated in the world of sports. Supporters of this method consider that this is a more correct way of grouping athletes giving greater equality in selection, training, and competition and so, decreasing the risk of injury. This paper aims to increase awareness and interest in bio-banding and for this reason, we analyzed the existent evidence on this topic to highlight the benefits, implications, limitations, importance, and impediments when it comes to applying it in the sports field.

Methods: For the literature review, we used Google Academic as a search engine and bio-banding as the main keyword. We chose to document this concept only regarding boys because approaching both genders is much more complex if we take into account the differences in terms of growth and maturation. To have a clear line of research, we chose to study this concept in terms of applicability in football, being a sport that is highly popular in our country.

Results: After the primary analysis we selected a total of 20 relevant studies that were analyzed and discussed to establish and highlight the advantages and disadvantages of this method of selection and grouping in sports.

Conclusion: Bio-banding can be a missing jigsaw of the training for youth athletes but further longitudinal studies are needed in order to clarify the advantages of bio-banding use.
\end{abstract}

Key words: Youth athletes, chronological age, biological age, maturation, talent identification, bio-banding

\section{Rezumat}

Introducere: Conceptul de bio-banding (BB) se referă la practica de grupare a sportivilor pe baza unor atribute asociate cu creșterea și maturizarea în loc de folosirea vârstei cronologice. În ultima vreme, avantajele și dezavantajele bio-bandingului sunt dezbătute pe scară largă în lumea sportului. Susținătorii acestei metode consideră că acesta presupune un mod mai corect de grupare a sportivilor, oferind o egalitate mai mare în selecție, antrenament și competiție contribuind astfel la diminuarea riscul de accidentare. Acest articol își propune să crească conștientizarea și interesul pentru acest subiect. Din acest motiv, am analizat dovezile existente în literatura de specialitate pentru a stabili și a evidenția beneficiile, implicațiile, limitările, importanța și impedimentele care pot apărea atunci când vine vorba de aplicarea acesteia în domeniul sportului. Metode: Pentru realizarea acestei lucrări, am folosit Google Academic ca motor de căutare și bio-banding ca principal cuvânt cheie.

Am ales să documentăm acest concept doar cu privire la băieți, deoarece abordarea ambelor sexe este mult mai complexă dacă luăm în considerare diferențele de creștere și maturizare. Pentru a avea o linie clară de cercetare, am ales să studiem acest concept din punct de vedere al aplicabilității în fotbal, fiind un sport cu popularitate ridicată în țara noastră.

Rezultate: După o analiza preliminară am selectat un total de 20 de studii relevante care au fost analizate și discutate pentru a stabili și evidenția avantajele și dezavantajele acestei metode de selecție și grupare în sport.

Concluzie: Bio-banding-ul poate repreenta veriga lipsă din antrenamentul tinerilor sportivi, dar sunt necesare studii longitudinale suplimentare pentru a clarifica avantajele utilizării bio-banding-ului.

Cuvinte cheie: tineret, vârstă cronologică, vârstă biologică, maturizare, identificarea talentelor, bio-bandin

\footnotetext{
${ }^{1}$ Lecturer, PhD, Physical Education and Sport Faculty, West University of Timișoara, Romania, e-mail: alexandra.rusu@e-uvt.ro

2 Lecturer, PhD, Faculty of Sociology and Psychology, West University of Timișoara, Romania

3 Student, Physical Education and Sport Faculty, West University of Timissoara, Romania
} 


\section{Introduction}

\section{What does bio-banding stand for?}

The bio-banding (BB) concept refers to the practice of grouping athletes on the basis of attributes associated with growth and maturation instead of chronological age [1].

Interest in this topic has a long history. More than 100 years ago, Crampton CW proposed the use of the term physiological age $[2,3]$. The classification of developmental stages was made based on the evolution of pubic hair (prepubescent, pubescent, post pubescent). Initially, this concept was approached in the context of establishing readiness of boys for the workforce. In that same period (1908), Rotch T.M., spoke about this concept under the name of "anatomical age" and proposed the use of wrist radiography as a form of measurement. He was also the one who suggested that this parameter could be used not only in schools, child labor but also in sports field [4].

Lately, the advantages and disadvantages of biobanding are widely debated in the world of sports. Supporters of this method consider that this is a more correct way of grouping athletes giving greater equality in training and competition and so, decreasing the risk of injury [5].

Biological maturation is considered to be an athletic performance indicator providing advantages in terms of strength, power, speed and other desirable attributes in sports. In this context, the mature athletes are more likely to be observed and selected [6-9]. Some authors consider that selection guided only by these criteria could be a good thing but only on short term. So, taller, stronger, faster athletes are easy to notice and favored in sports selection compared to those athletes who have not yet reached biological maturity, but which may be more talented or more technical.

The maturation level is established based on percentage of predicted adult height, or based on sexual maturation or skeletal age.

Children with early maturation may benefit from selection and special attention as a level of training, but may also have problems with overload. Athletes with late development are stimulated to develop technique and tactics more than their teammates who can relay early on physical qualities. Some studies even show that the selection rate is high for children born in the first decade of the age category, to the detriment of those born in the second decade, but who may in time, with the right stimulation, become better athletes.

Why we consider that this is a topic that deserves attention? Studies have shown that every child has its own maturation speed. Same age kids can be at different levels of biological maturation. This parameter has an important role in competition and can mislead the process of selection, disadvantaging the talented, skilled, but biologically unmaturated kids, giving an advantage in terms of speed and force to the biologically mature kids.

Grouping and selection on chronological rather than biological criteria can therefore rise psychoemotional problems for children with late maturation because they feel overwhelmed by their opponents of the same age, but much stronger. This disadvantage, although temporary, can discourage, at some point, talented kids who feel that they are not performing well enough in terms of physical qualities (speed, force, power, velocity, reaction speed). On the other hand, for those with early maturation there may be the problem of insufficient stimulation in the context of their inclusion in a group with a predominantly late level of maturation.

In late adolescent and early adulthood, this temporary advantage/disadvantage tends to become unnoticeable and the chronological age selection criteria is starting to show its biases [10].

From here, a logical question arises. Which is the most appropriate way to group athletes for training and competition and which is the most efficient form of selection on long-term?

In this context, we consider it important to evaluate and present the BB value, implications and practical limitations.

This paper aims to increase awareness and interest in the bio-banding and, for this reason, we analyzed the existent evidence on this topic in order to highlight the benefits, implications, limitations, importance and impediments when it comes to applying it in the sports field.

\section{Methods}

For the literature review, we used Google Academic as search engine (because it offers full-text search of scientific publications in all formats and disciplines and it includes most online journals in Europe and 
America of the largest scientific publications), and bio-banding as a main key word. We selected and reviewed recent articles that discussed the concept of $\mathrm{BB}$ and presented the advantages and disadvantages of the method.

We chose to document this concept only regarding boys because approaching both genders is much more complex if we take into account the differences in terms of growth and maturation. In order to have a clear line of research, we chose to study this concept in terms of applicability in football, being a sport that is highly popularin our country.

We included only the studies that evaluate the biobanding concept in the context of sports field and especialy in football.

This study is just the top of the iceberg for this complex concept that needs more attention and more interventional, practical and concept clarifying studies.

\section{Results}

Initially, we analyzed the concept of bio-banding in a general context. Subsequently, only those studies that addressed our topic of interest in the field of football were selected for analysis.

The inclusion criteria refered to the studies from the last 10 years that approached the chosen subject from the point of view of the implications related to the selection and training process in footbal. 20 studies were selected, analyzed and discussed to establish and highlight the advantages and disadvantages of this method of selection and grouping in sports.

\section{Discussions}

The study of the influence of maturation in sports performance and of the efficiency of bio-banding method, has intensified in the last 5 years. Being a still fresh topic, it raises a large number of questions, starting from: which are the best ways to assess the biological maturity status, up to the practical reasonableness of the method. According to a study from 2017, in youth sports, the assessments of secondary sex characteristics, skeletal age, or age at peak height velocity (PHV) estimation are impractical, and more practical ways are considered to be the percentage of predicted adult stature and the maturity offset [1]. On the other hand, a study from 2018 presents the predicted maturity offset and age at peak height velocity as increasingly used with youth athletes, although validation studies indicated major limitations. They also proposed and tested new equations that seem to be useful for average maturing boys close to the time of peak height velocity, but these new and original equations may have major limitations with early and late maturing boys and girls.

Methods of assessing biological maturity like sexual maturity, bone maturity, estimated maturity (using formulas), testosterone plasma concentration, have different levels of accessibility and reliability. Unfortunately, the most accurate methods are less accessible.

Some studies state that the transition from childhood to puberty is characterized not only by changes in sexual maturation, but also by changes in body composition and physical performance, materialized in differences in performance, but also in body size [11]. Individuals with earlier maturation tended to have higher BMI values, higher values for body fat, which tend to last, increasing the risk of overweight in adulthood. This observation may not be verified at high competitive levels where the workload is high and, consequently, the risk of overweight is low, but it can be taken into account in the selection process at lower levels [12].

From our point of view, the concept must be analyzed from 3 directions: training, competition and selection

\section{Bio-banding for training optimization and injury risk reduction}

Physical training specialists recommend adapting evaluation, training and conditioning programs based on individual differences in growth and maturation status [1].

In the pre-pubertal phase, the main adaptations, when it comes to strength, speed and power, are achieved by adapting the neuromuscular system, while in the post-pubertal phase the child becomes faster, stronger, due to the increase in cross section of the muscle, based on hormonal mechanisms.

A critical period is represented by the rapid growth phase in which the risk of injury increases, requiring greater attention to the load and recovery from training. 
Rapid growth, can be accompanied by "adolescent awkwardness" (decreases in movement skills), due to the rapid changes in size and proportions, coupled with changes in how the brain processes information about body positioning and this may affect neuromuscular control and proprioceptive ability and result in motor and functional performances decline, increasing the risk of injury [1]. Differences between kids related to growth rate, height and bone mass, occurring between stages 2 and 3 (pubic hair) of puberty, may increase the risk of fractures during this period $[1,13,14]$.

To optimize training effects and ensure athlete safety, practitioners should consider the above mentioned information [15].

2. In competition, we can encounter two situations: lack of challenge when competing against physically smaller and less able players - for early maturing boys, and long term greater challenge - for late maturing boys.

Advantages and disadvantages for early maturing boys

They often limit the development of the psychological, technical and tactical skills because they can use their size and strength as advantages. But this can be a disadvantage in the adulthood when these attributes become important for success [5].

Maturity-associated advantages in size and function are attenuated and/or reversed in late adolescence and adulthood [16].

Advantages and disadvantages for late maturing boys

Late maturing players may benefit in the long-term from exposure to greater challenge, but this is valid only if the players are retained within the academy programs.

Regarding this, studies show that late maturing youth represented less than 5\% of U15 and U17 players in an English academy [17].

3. In selection, the bias towards advanced maturity status emerges in at approximately 12-13 years and increases with age and level of competition $[18,19]$. Early maturing players are more likely to have access to specialist coaching, training resources and higher standards of competition and challenge [20-
22]. In contrast, late maturing youth are more likely to be overlooked, excluded and/or denied these developmental opportunities [23].

A recent study of Swiss junior footballers demonstrated that late maturing players remain disadvantaged, despite being more technically and psychologically gifted [24].

It is possible that some of the late maturing players were relatively young for their age-group and also less advanced in growth (i.e. smaller). In contrast, a study of the youth characteristics of U13 and U15 soccer players who were playing regionally and nationally as adults indicated no differences in the skeletal maturity and pubertal status [16].

\section{Chronological age, biological age and relative age}

Sometimes, in practice, there are cases when specialists use selection criteria based on relative age. This means they favor early born players from the same competitive age group. So, early born players are more likely to be selected in youth sports programs, based on the fact that they are relatively older and biologically more mature and, thus physically and functionally superior. But relative age is not always correlated with maturational status in young athletes, but rather with inherited characteristics.

As we know, the standard classification in youth sports remains the one based on the birth date, despite the possible differences between children of the same chronological age $[11,12]$.

\section{Athletes perception}

A study published in 2019 in Annals of Human Biology, evaluated how the players perceive biobanding, and they found two points of view: early maturing players perceived greater physical and technical challenge, and, in turn, new opportunities and challenges. Late maturing players perceived less physical and technical challenge, yet greater opportunity to demonstrate technical and tactical abilities [24].

\section{Does maturity status 'bio-banding' work?}

Some investigators concluded that 'bio-banding' is an effective tool for selection, if we consider not only physical, but also technical, tactical and psychological player attributes when it comes to 
talent identification. Moreover, some argue that bio-banded competition, as an adjunct to the existing program, would allow youth athletes of varying maturation groups to develop a variety of technical skills, encouraging their holistic development [25].

Others consider that the bio-banding method of grouping players should be used occasionally by clubs and coaches as a hybrid method of training and playing. Bio-banding can be considered a tool that can be used to better understand and promote the development and well-being of young athletes. Practitioners claim that it cannot be a substitute for age group training or competitions but rather an adjunct activity that has the potential to challenge the athlete in a unique manner, and to create a more diverse and developmentally appropriate learning environment. A more effective athlete development program can include both age groups and biobanded activities, which offer athletes a more diverse and adapted to the individual development stimulus. It is recommended to have an adapted approach which can involve bio-banded competitions as part of the existing game program, one or two times a month $[1,26]$.

Regarding maturity assessments accessible to field conditions, further studies for validation are needed. Biological growth and maturation, and psychological and social development do not progress in synchrony [1].

\section{Conclusions}

Bio-banding can be a missing jigsaw of the training for youth athletes. This system promises to provide equal opportunities for children in different stages of maturation. Children who mature early improve their technical and tactical qualities, giving up abusing the physical qualities that gave them advantages over children who mature later. Children who mature later can benefit from a higher density of technical elements and can maintain/improve their self-esteem.

Based on the above conclusions we consider that this method can be beneficial in training, selection and competition.

These findings are part of preliminary research. The benefits of bio banding must be verified in longitudinal studies to determine the long-term effects. The implementation of this system may raise difficulties for coaches, parents and children in the absence of a complete information program on this process. $\mathrm{BB}$ does not change the current paradigm of youth training, but it can complete it taking into account the biological age.

Maturity assessments applicable to field conditions need further study and validation. Biological growth and maturation, and psychological and social development do not progress in synchrony.

Knowinghow to best assess and evaluate biological, psychological, and social readiness is essential for improving the effectiveness of bio-banding strategies.

For a better understanding of the concept and its effectiveness in psychological and social terms, but also regarding physical training and selection, additional studies are needed to clarify both concepts related to evaluation and implementation. 


\section{References}

1. Cumming S. P., Lloyd R. S., Oliver J.L., Eisenmann J.C., Malina R.M. (2017). Bio-banding in sport: applications to competition, talent identification, and strength and conditioning of youth athletes. Strength \& Conditioning Journal, 39(2), 34-47.

2. Crampton C.W. (1908). Physiological age-a fundamental principle. American Physical Education Review, 13(4), 214227.

3. Rotch TM. (1908). Chronological and anatomical age early in life. Journal of the American Medical Association, 51(15), 1197-1205.

4. Rogol A.D., Cumming S.P., Malina R. M. (2018). Biobanding: a new paradigm for youth sports and training. Pediatrics, 142(5),1-2.

5. Cumming S.P., Brown D. J., Mitchell S., Bunce J., Hunt D., Hedges, C., \& Breakspear D. (2018). Premier League academy soccer players' experiences of competing in a tournament bio-banded for biological maturation. Journal of Sports Sciences, 36(7), 757-765

6. Meylan C., Cronin J., Oliver,J., \& Hughes M. (2010). Talent Identification in Soccer: The Role of Maturity Status on Physical, Physiological and Technical Characteristics. International Journal of Sports Science \& Coaching, 5(4), 571-592.

7. Baxter-Jones A. D., Thompson A. M., \& Malina R.M. (2002). Growth and maturation in elite young female athletes. Sports Medicine and Arthroscopy Review, 10(1), 42-49.

8. Tangalos, C., Robertson, S. J., Spittle, M., \& Gastin, P. B. (2015). Predictors of individual player match performance in junior Australian football. International journal of sports physiology and performance, 10(7), 853-859.

9. Buchheit M., Mendez-Villanueva A. (2014). Effects of age, maturity and body dimensions on match running performance in highly trained under-15 soccer players. Journal of Sports Sciences, 32(13), 1271-1278.

10. Johnson A., Farooq A., \& Whiteley R. (2017). Skeletal maturation status is more strongly associated with academy selection than birth quarter. Science and Medicine in Football, 1(2), 157-163.

11. Mirwald RL, Baxter-Jones ADG, Bailey DA, Beunen GP. (2002). An assessment of maturity from anthropometric measurements. Medicine \& Science in Sports \& Exercise, 34(4), 689-694

12. Freitas A. S., Figueiredo A. J., de Freitas A. L., Rodrigues V. D., da Cunha A.A., Deusdará F.F., \& Coelho M. J. (2014). Biological maturation, body morphology and physical performance in 8-16 year-old obese girls from Montes Claros$M G$. Journal of Human Kinetics, 43(1), 169-176.

13. Bisi M. C., \& Stagni R. (2016). Development of gait motor control: what happens after a sudden increase in height during adolescence? Biomedical engineering online, 15(1), 47.

14. Quatman-Yates C. C., Quatman C. E., Meszaros, A. J., Paterno M. V., \& Hewett T.E. (2012). A systematic review of sensorimotor function during adolescence: a developmental stage of increased motor awkwardness? British Journal of Sports Medicine, 46(9), 649-655.

15. Malina R. M. (2011). Skeletal age and age verification in youth sport. Sports medicine, 41(11), 925-947.

16. Malina R. M., Cumming S. P., Rogol A. D., Coelho-e-Silva M. J., Figueiredo A. J., Konarski J. M., \& Kozieł S. M. (2019). Biobanding in youth sports: Background, concept, and application. Sports Medicine, 1-15.

17. Johnson A., Farooq A., \& Whiteley R. (2017). Skeletal maturation status is more strongly associated with academy selection than birth quarter. Science and Medicine in Football, 1(2), 157-163.

18. De Silva M. C., Figueiredo A. J., Simoes F., Seabra A., Natal A., Vaeyens, R., \& Malina, R. M. (2010). Discrimination of U-14 soccer players by level and position. International journal of sports medicine, 31(11), 790-796.

19. Figueiredo A. J., Gonçalves C. E., Coelho e Silva M. J., \& Malina R. M. (2009). Characteristics of youth soccer players who drop out, persist or move up. Journal of sports sciences, 27(9), 883-891.

20. Baker J., Horton S., Robertson-Wilson J., \& Wall M. (2003). Nurturing sport expertise: factors influencing the development of elite athlete. Journal of sports science \& medicine, 2(1), 1.

21. Malina R. M. (2003). 20 Growth and maturity status of young soccer players. Science and soccer, 287.

22. Malina R. M., Rogol A. D., Cumming S. P., De Silva M. J. C., \& Figueiredo A. J. (2015). Biological maturation of youth athletes: assessment and implications. British Journal of Sports Medicine, 49(13), 852-859.

23. Cobley S. (2016). Talent identification and development in youth sport. In Routledge handbook of youth sport, 506521.

24. Bradley B., Johnson D., Hill M., McGee D., Kana-Ah, A. Sharpin, C. \& Malina, R. M. (2019). Bio-banding in academy football: player's perceptions of a maturity matched tournament. Annals of human biology, 46(5), 400-408.

25. Abbott W., Williams S., Brickley G., \& Smeeton N.J. (2019). Effects of Bio-Banding upon Physical and Technical Performance during Soccer Competition: A Preliminary Analysis. Sports, 7(8), 193.

26. Tucker R., Raftery M., \& Verhagen E. (2016). Injury risk and a tackle ban in youth Rugby Union: reviewing the evidence and searching for targeted, effective interventions. A critical review. British Journal of Sports Medicine, 50(15), 921-925. 